\title{
Wind mixing, food availability and mortality of anchovy larvae Engraulis encrasicolus in the northern Adriatic Sea
}

\author{
S. H. Coombs ${ }^{1, *}$, O. Giovanardi ${ }^{2}$, N. C. Halliday ${ }^{1}$, G. Franceschini ${ }^{2}$, D. V. P. Conway ${ }^{1}$, \\ L. Manzueto ${ }^{2}$, C. D. Barrett ${ }^{3}$, I. R. B. McFadzen ${ }^{4}$ \\ ${ }^{1}$ Marine Biological Association of the United Kingdom, The Laboratory, Citadel Hill, Plymouth PL1 2PB, United Kingdom \\ ${ }^{2}$ Istituto Centrale per la Ricerca scientifica e tecnologica Applicata al Mare, Viale Stazione 5, 30015 Chioggia (VE), Italy \\ ${ }^{3}$ Plymouth Marine Laboratory, Prospect Place, The Hoe, Plymouth PL1 3DH, United Kingdom \\ ${ }^{4}$ Coastal and Marine Biotechnologies Ltd., Tamar Science Park, Plymouth PL6 8BX, United Kingdom
}

\begin{abstract}
A study was carried out in June/July 1996 in the River Po outflow in the northern Adriatic to investigate spawning of anchovy Engraulis encrasicolus and survival of larvae in relation to food availability and wind mixing. Hydrographic- and bongo net sampling was carried out on 2 grid surveys; one after a period of low winds and settled weather, and the other after an intervening period of strong winds, which resulted in a decrease in water column stratification. The spawning areas of anchovy and the larval distributions were associated with the river outflow plume (most clearly on the second survey grid, after the period of higher winds). Potential food particles for anchovy larvae, primarily copepod nauplii and copepodite stages, were also concentrated in the area influenced by the river outflow. Although there was a nearly $50 \%$ reduction in the mean water column abundance of potential food particles between the 2 survey grids, mostly due to a decline in abundance outside the immediate river plume area, there was no significant change in mortality of anchovy larvae between the 2 grids; the exponential decline in numbers of eggs and larvae to $10 \mathrm{~mm}$ in length being equivalent to overall mortality rates of $43.2 \% \mathrm{~d}^{-1}$ on the first survey and $44.7 \% \mathrm{~d}^{-1}$ on the second. The resilience of larval survival under potentially less favourable feeding conditions, following the period of wind mixing, was ascribed, in part, to the maintenance of local water column stratification by the superficial low salinity input from the River Po. This stratification in the immediate outflow area was associated with the presence of concentrated layers of potential food particles (typically $>50$ particles $1^{-1}$ and 1.5 to 2.8 times the mean water column abundance) in the upper $10 \mathrm{~m}$ of the water column, coincident with peak numbers of anchovy larvae. However, since there was no evidence for lower larval survival in areas, less influenced by the immediate river outflow plume, a simple direct relationship between enhanced water column stability, improved feeding conditions and larval survival was not supported.
\end{abstract}

KEY WORDS: Engraulis encrasicolus · Anchovy · Eggs · Larvae · Mortality · Feeding conditions · Wind mixing

Resale or republication not permitted without written consent of the publisher

\section{INTRODUCTION}

It is well documented that the fortunes of marine fisheries vary over a range of time-scales (e.g. Cushing 1995). For small, short-lived pelagic species, such as anchovy Engraulis encrasicolus, sardine Sardina pilchardus and sprat Sprattus sprattus, the wide year-to- year fluctuations in adult biomass depend largely on the size of each incoming year class (Hunter \& Alheit 1994), which in turn, is a reflection of the cumulative mortality during the pre-recruit stages.

Food availability and predation are recognised as 2 of the principal influences on larval mortality (e.g. Bailey \& Houde 1989). Specific links between food 
availability and larval survival have been investigated both in terms of general levels of food abundance (e.g. Economou 1987) and in relation to the structure and persistence of local concentrations of food particles (e.g. Nakata et al. 1995, Lochmann et al. 1997). The benefits of vertically structured aggregations of food particles for larval survival were highlighted by Lasker (1975), such vertical structuring of the plankton being related to wind mixing and water column stability (e.g. Peterman \& Bradford 1987, Kendall et al. 1996, Lagadeuc et al. 1997). Wind mixing also affects larval feeding through its influence on predator/prey contact rates (Dower et al. 1997, Sundby 1997) and consequent larval feeding success (Rothschild \& Osborn 1988). However, considering the effort that has been applied to such studies, there remains relatively little evidence of starvation induced mortality or of the effects of wind mixing on larval mortality (Heath 1992).

Moser \& Pommeranz (1999) postulated reduced numbers of Engraulis mordax larvae off California following a wind event as being due, possibly, to disturbance of microscale food patches, although food levels were higher after the period of wind mixing. Similarly, Bergeron (2000), using nucleic acid as a measure of larval condition for E. encrasicolus in Biscay, found wind mixing resulted in larvae in poorer condition. Other studies on anchovy in the Bay of Biscay (Borja et al. 1998, Allain et al. 2001), noted that low winds were favourable for anchovy recruitment in promoting weak upwelling and hence, enhanced production and extension of river plumes. However, none of the above studies included measurements of larval mortality rates related directly to food availability.

In the Adriatic, anchovy spawning is widespread, but generally at higher levels in the more northern areas and in particular, in the study area around the outflow of the River Po (Piccinetti et al. 1980). In this region, the river discharge enhances stratification and dominates the distribution and production of phytoplankton and zooplankton (Gilmartin \& Revelante 1981, Smodlaka \& Revelante 1983, Fonda Umani 1996). During the main summer spawning season of anchovy, the meteorological situation is stable and the water column is generally well stratified. This is disturbed intermittently by an intense north-easterly katabatic wind (the 'Bora') which is most prevalent in the late summer and autumn, but which can occur for periods of up to a few days at other times of the year. The effect of this wind on mixing, water mass advection and the production regime has been noted by Malanotte-Rizzoli \& Bergamasco (1983) and Zore-Armanda \& Gačić (1987). The ultimate meteorological control of water circulation in the Adriatic and consequent changes in production, larval survival and abundance of anchovy have also been discussed briefly by Bombace (1992) and Regner (1996).

It was in this context that a joint study Anchovy Larvae In Contrasting Environments (ALICE) was initiated to investigate the survival of anchovy larvae in relation to changing hydro-meteorological conditions and food availability. The selected study area in the northern Adriatic provided a relatively well defined spawning area which is subject to periodic strong winds. This provided the possibility to study larval mortality and food availability in relation to changes in the physical environment under natural conditions. Results from the main field investigations carried out in 1996 are reported here; preliminary studies completed in 1995 are described in Coombs et al. (1997) and McFadzen \& Franceschini (1997).

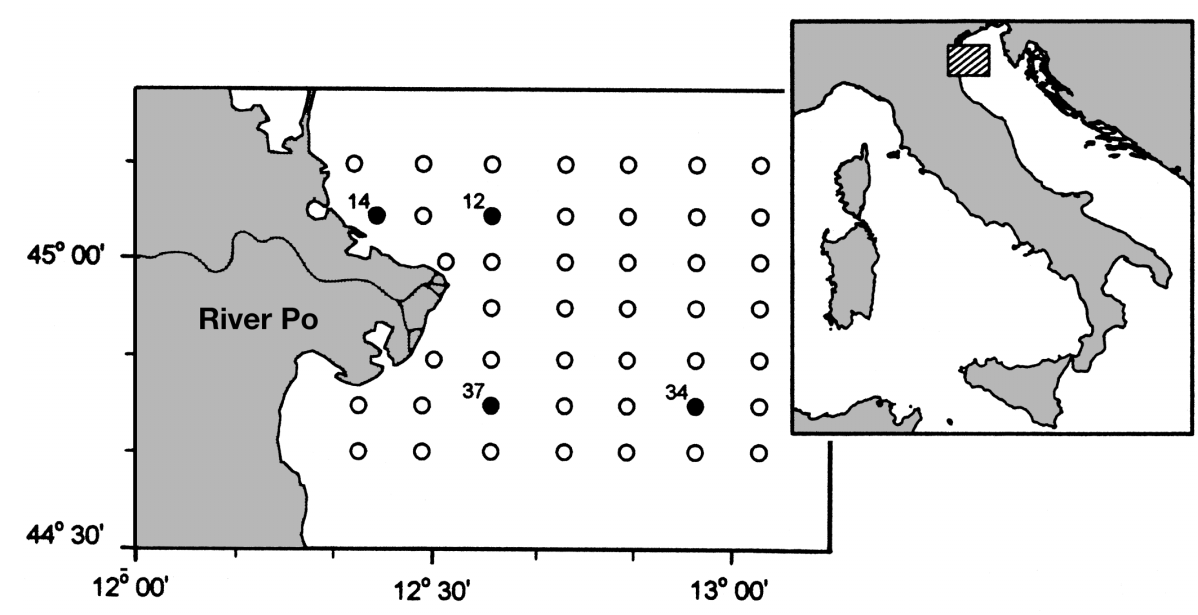

Fig. 1. Sampling area showing the bongo grid and Longhurst-Hardy plankton recorder (LHPR) stations $(\bullet)$ with adjacent station identification numbers

\section{MATERIALS AND METHODS}

Bongo grid. Plankton sampling for determining the regional distribution of anchovy eggs and larvae and food abundance was carried out by bongo net tows over a 5 nautical mile grid of 45 stations (Fig. 1). This grid was sampled first between 16 and 18 June 1996 and for a second time between 2 and 4 July 1996. On both grids, sampling was done both during the day and night. A double bongo net system was used, consisting of a $30 \mathrm{~cm}$ diameter sampler fitted with $280 \mu \mathrm{m}$ mesh nets for collection of fish eggs and larvae and, 
suspended below it, a $9 \mathrm{~cm}$ diameter bongo system with $53 \mu \mathrm{m}$ mesh nets for sampling the microzooplankton. Both bongo systems were fitted with flowmeters to allow standardisation of the catch to unit volume filtered. A nominal towing speed of 2 knots was employed on a double oblique haul sampling from the surface to $\sim 2 \mathrm{~m}$ above the sea bed. Real-time monitoring of sampler depth trajectory, together with sensor readings for flow, temperature and salinity were obtained with an electronic sensor package mounted above the nets. Following each haul, the plankton samples were preserved in $4 \%$ borax buffered, freshwater formaldehyde solution.

Subsequent microscope identification was carried out for eggs and larvae of anchovy, their numbers then being standardised to numbers $\mathrm{m}^{-2}$ using the computed volume of water filtered and maximum depth sampled. All specimens post-hatch are here referred to generally as 'larvae', which is taken to include the specific stage of 'yolk-sac larvae'. Lengths are total lengths of preserved specimens. Larvae are grouped into $1 \mathrm{~mm}$ size categories referred to by the mid-points of the category intervals (i.e. the $6.5 \mathrm{~mm}$ category represents larvae between 6.00 and $6.99 \mathrm{~mm}$ in length).

Microzooplankton samples were analysed for potential food items for anchovy larvae (mostly nauplii and copepodite stages of copepods; Conway et al. 1998, Tudela et al. 2002) the numbers being converted to numbers $\mathrm{l}^{-1}$ using the computed volume of water filtered from the flowmeter readings. The values given by Hay et al. (1988) and Thompson \& Harrop (1991) were used for conversion of numerical abundance to dry weight.

All bongo grid data, both biological and physical, were contoured with the SURFER software package using kriging as the interpolation routine.

Vertical distribution sampling. Vertical distribution sampling was carried out by means of paired day/night Longhurst-Hardy plankton recorder (LHPR) hauls (Williams et al. 1983, see also Pipe et al. 1981) taken at 4 station positions at intervals through the cruise period (Fig. 1, Table 1). At each station, the positions of consecutive hauls followed the track of a sub-surface drogue (at $7 \mathrm{~m}$ depth) which was released at the start of each station visit to allow, as far as possible, the same water mass to be sampled repeatedly. A nominal towing speed of 3 knots was employed on a single oblique haul, sampling on the descent phase from the surface to $\sim 1 \mathrm{~m}$ above the sea bed.

The LHPR system consisted of a main 'coarse' net system of 280 or $500 \mu \mathrm{m}$ mesh (selected according to ambient plankton concentration) for sampling the ichthyoplankton and, mounted on the same sampler frame, a smaller 'fine' net system of $53 \mu \mathrm{m}$ mesh for concurrent sampling of microzooplankton. Both nets terminated in cod-end units in which consecutive plankton samples were collected at $1 \mathrm{~min}$ intervals to give a vertical resolution of $\sim 2 \mathrm{~m}$. An electronics package on the sampler frame allowed real-time transmission of data via cored cable for onboard PC display of system function, including readings from sensors for depth, temperature, salinity (conductivity), chlorophyll a (chl a) and water flow for each sample.

Sample treatment and analysis were the same as for the bongo net samples. Analysis results were standardised to give vertical distribution plots, taking into account the depth range over which each sample was taken and the volume of water filtered. Plots of the mean vertical distribution of eggs and larvae of

Table 1. Longhurst-Hardy plankton recorder (LHPR) haul information

\begin{tabular}{|c|c|c|c|c|c|c|}
\hline \multirow{3}{*}{$\begin{array}{l}\text { Haul } \\
1\end{array}$} & \multirow[t]{2}{*}{ Date } & \multirow{2}{*}{$\begin{array}{c}\text { Start time } \\
(\text { local }=\text { GMT }+2 \mathrm{~h})\end{array}$} & \multirow{2}{*}{ Stn } & \multirow{2}{*}{$\begin{array}{l}\text { Sample depth } \\
\text { (m) }\end{array}$} & \multicolumn{2}{|c|}{ No. of samples } \\
\hline & & & & & Coarse & Fine \\
\hline & 21 Jun 96 & $11: 30$ & 14 & 20.4 & 11 & 11 \\
\hline 2 & 27 Jun 96 & $10: 15$ & 14 & 14.8 & 10 & 10 \\
\hline 3 & 27 Jun 96 & $15: 20$ & 12 & 20.8 & 17 & 20 \\
\hline 4 & 27 Jun 96 & $22: 40$ & 12 & 27.2 & 15 & 15 \\
\hline 5 & 28 Jun 96 & $02: 18$ & 12 & 25.0 & 14 & 14 \\
\hline 6 & 28 Jun 96 & $10: 20$ & 12 & 29.7 & 14 & 14 \\
\hline 7 & 28 Jun 96 & $15: 10$ & 37 & 26.2 & 13 & 13 \\
\hline 8 & 28 Jun 96 & $22: 30$ & 37 & 24.7 & 15 & 15 \\
\hline 9 & 29 Jun 96 & 01:55 & 37 & 25.3 & 18 & 18 \\
\hline 10 & 29 Jun 96 & $10: 10$ & 37 & 26.3 & 12 & 12 \\
\hline 11 & 04 Jul 96 & $13: 38$ & 34 & 35.2 & 21 & 21 \\
\hline 12 & $04 \mathrm{Jul} 96$ & $22: 15$ & 34 & 36.5 & 17 & 17 \\
\hline 13 & 06 Jul 96 & $12: 40$ & 12 & 26.6 & 9 & 9 \\
\hline 14 & 06 Jul 96 & $16: 00$ & 12 & 27.5 & 12 & 12 \\
\hline 15 & $06 \mathrm{Jul} 96$ & $22: 30$ & 12 & 27.5 & 10 & 10 \\
\hline 16 & 07 Jul 96 & $02: 20$ & 12 & 27.2 & 12 & 12 \\
\hline 17 & 07 Jul 96 & $13: 30$ & 14 & 18.5 & 15 & 15 \\
\hline 18 & 07 Jul 96 & $22: 30$ & 14 & 18.6 & 13 & 13 \\
\hline 19 & 09 Jul 96 & $14: 50$ & 37 & 25.9 & 14 & 14 \\
\hline 20 & 09 Jul 96 & $22: 40$ & 37 & 25.9 & 14 & 14 \\
\hline 21 & $10 \mathrm{Jul} 96$ & $02: 20$ & 37 & 27.2 & 12 & 12 \\
\hline 22 & $10 \mathrm{Jul} 96$ & $10: 30$ & 37 & 28.5 & 10 & 10 \\
\hline 23 & $10 \mathrm{Jul} 96$ & $15: 45$ & 34 & 35.9 & 15 & 15 \\
\hline 24 & $10 \mathrm{Jul} 96$ & $22: 30$ & 34 & 36.1 & 13 & 13 \\
\hline 25 & $11 \mathrm{Jul} 96$ & $11: 00$ & 12 & 27.5 & 12 & 12 \\
\hline 26 & $11 \mathrm{Jul} 96$ & $16: 35$ & 12 & 25.6 & 12 & 12 \\
\hline 27 & $11 \mathrm{Jul} 96$ & $22: 30$ & 12 & 25.6 & 12 & 12 \\
\hline 28 & $12 \mathrm{Jul} 96$ & $02: 30$ & 12 & 26.2 & 14 & 14 \\
\hline 29 & $12 \mathrm{Jul} 96$ & $13: 15$ & 14 & 19.2 & 11 & 0 \\
\hline 30 & 12 Jul 96 & $22: 30$ & 14 & 16.3 & 11 & 11 \\
\hline
\end{tabular}


Table 2. Engraulis encrasicolus. Estimated age of eggs and larvae

\begin{tabular}{|lc|}
\hline $\begin{array}{l}\text { Development stage/ } \\
\text { larval length (mm) }\end{array}$ & $\begin{array}{c}\text { Computed age at mid-point } \\
\text { of development stage } \\
\text { (days from fertilisation) }\end{array}$ \\
\hline Egg & 0.72 \\
$<3$ & 1.91 \\
3.5 & 2.81 \\
4.5 & 3.87 \\
5.5 & 5.11 \\
6.5 & 6.39 \\
7.5 & 7.67 \\
8.5 & 8.95 \\
9.5 & 10.23 \\
\hline
\end{tabular}

anchovy were prepared using the standardised data for each haul converted to percentage occurrence down the water column (i.e. giving equal weighting to each haul), with only those hauls on which 20 or more eggs or larvae occurred for any particular egg stage or size group being included for derivation of mean profiles. Dispersion indices were calculated as the ratio of the SD of abundance in all depth strata on a single LHPR haul to the mean abundance for all strata.

Egg and larval mortalities. Egg and larval mortality rates were derived for each of the 2 bongo grids from semi-log plots of mean abundance (numbers $\mathrm{m}^{-2}$ ) of total eggs, and $1 \mathrm{~mm}$ size categories of larvae for all bongo samples on each sampling grid and from sub-sets of stations according to surface salinity and water column stratification. The abundance values were first corrected to a unit time interval of $1 \mathrm{~d}$ by dividing by the relevant duration of development and then plotted against age at the mid-point of each stage (Table 2).

The duration of embryonic development was taken from Regner (1985), while larval growth rate $(0.78 \mathrm{~mm}$ $\mathrm{d}^{-1}$ ) and length at the start of first ring deposition $(4.2 \mathrm{~mm})$ were estimated from a functional regression (Ricker 1973) of otolith ring count against larval length for specimens sampled on the same cruise (G. Franceschini pers. comm.). Length at hatching $(2.0 \mathrm{~mm})$ was estimated from the smallest consistent size group of larvae observed in the bongo net samples. Time from hatching until start of otolith daily growth ring deposition (2 d) was based on laboratory observations in the present programme and results presented by Kornilova (1955), Duka (1963), Regner (1972, 1985), Palomera et al. (1988) and Dulčić \& Kraljevic (1996).

All the above literature-derived values were interpolated for a temperature of $22.7^{\circ} \mathrm{C}$, this being the mean temperature in the upper $10 \mathrm{~m}$ of the water column in which most of the anchovy eggs and larvae occurred, for the 2 bongo grids combined. Although temperatures differed by some 2 to $3^{\circ} \mathrm{C}$ between the 2 bongo grids, use of a common reference temperature was required because the available parameter values were not sufficiently precise to resolve differences within this range.

Hydrography. Vertical profiles of temperature and salinity were obtained on all bongo net hauls from a sensor system mounted above the net frame. Additional profiles, which also included data for chl $a$, were obtained at selected stations with the LHPR system and using a Sea-Bird 911 series CTD.

Daily average flow rates for the River Po were provided by the Ufficio Idrografico di Parma.

Meteorology. Measurements of atmospheric pressure, air temperature, wind speed and direction were obtained from 3 hourly data at Venice airport. Pressure and temperature were processed to give daily means. A 3 day running mean of the cube of wind speed was used as a smoothed index of water column mixing (Richman \& Garrett 1977).
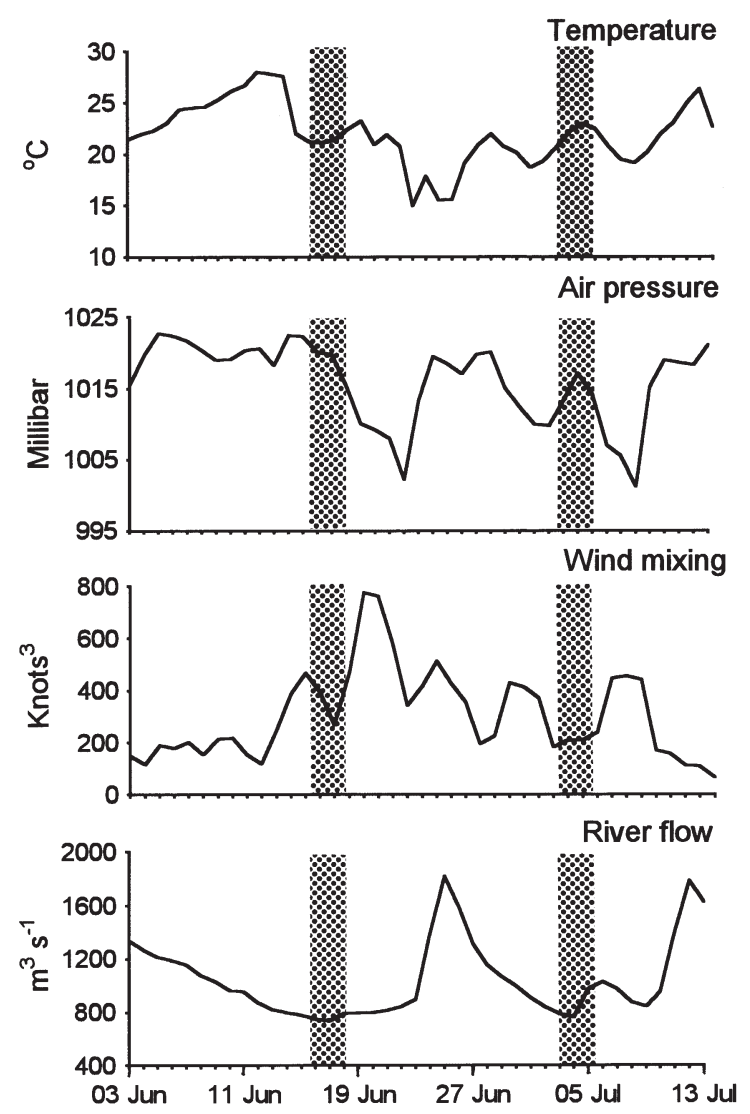

Fig. 2. Mean daily air temperature, mean daily air pressure, 3 day running mean of wind speed cubed (as an index of water column mixing) and daily average flow rates of the River Po for the cruise period and preceding $2 \mathrm{wk}$. The stippled bars show the 2 sampling periods for the bongo grids 


\section{RESULTS}

\section{Meteorological and hydrographic conditions}

In the 2 wk prior to the first bongo grid, there was a stable, high pressure weather pattern, resulting in low winds and a progressive increase in daily air temperatures (Fig. 2). A series of depressions and associated fronts then skirted or passed through the northern Adriatic, these being evident as successive periods of reduced atmospheric pressure, lowered air temperature and increased wind mixing. Particularly stormy weather was experienced from 19 to 23 June, just after the first bongo grid, with the occurrence of a short period of strong north-easterly 'Bora' winds of $20+$ knots. Unsettled weather continued through the second bongo grid, sampled between 2 and 4 July, with continuously low winds returning only in the last few days of the cruise from about 9 July (Fig. 2).

Flow of the River Po showed a smooth, lagged response to the regional weather pattern as characterised by the air pressure (Fig. 2). Thus, there was a steady decrease in flow rate in the $2 \mathrm{wk}$ prior to the first bongo grid when weather conditions were stable. Following the period of poor weather from 19 to 23 June, there was a dramatic increase in flow rate which declined gradually after a few days. Towards the end of the sampling period, following a trough of low pressure on 7-8 July, there was a second increase in river flow accompanied by low winds.

An equivalent contrast was observed in hydrographic conditions on the 2 bongo grids. On the first grid (16 to 18 June) much of the survey area was covered by warm surface water $\left(>22^{\circ} \mathrm{C}\right)$ with a marked tongue of the warmest water $\left(>25^{\circ} \mathrm{C}\right)$ extending in a south-west to north-east band from the Po delta. Low salinity water was distributed rather more symmetrically around the delta and eastwards across the sampling area, with values ranging from $<30$ salinity units at the coast to $>38$ units in the extreme south-east. The combination of these 2 elements of water column stability resulted in highest stratification ( 0 to $20 \mathrm{~m}, \Delta \sigma_{\mathrm{t}}>6 \mathrm{~kg}$ $\mathrm{m}^{-3}$ ) immediately adjacent to the Po outflow, with relatively high values extending to the east and north-east (Fig. 3). Due to the intervening period of intermittent high winds, there was a marked change in conditions on the second bongo grid of 2 to 4 July. Surface temperature was lower and varied little over the survey area, being mostly between 21 and $22^{\circ} \mathrm{C}$. Surface salinity was similar to the pattern observed on the first grid, but with the area of lowest salinities ( $<32$ units) being more localised immediately around the river mouth. The net result, in terms of water column stratification, was a lower but still appreciable level of stability ( 0 to $20 \mathrm{~m}, \Delta \sigma_{\mathrm{t}}>3 \mathrm{~kg} \mathrm{~m}^{-3}$ ) compared with the first bongo grid, in a similar south-west to north-east alignment from the mouth of the River Po.

\section{Vertical distribution of anchovy eggs and larvae}

Anchovy eggs were found mostly in the upper $10 \mathrm{~m}$ of the water column ( $80 \%$ in the 0 to $10 \mathrm{~m}$ depth range) and typically in progressively increasing abundance towards the surface (Fig. 4). Although the relationship between their vertical distribution and hydrographic structure was variable, eggs were generally confined to depths above the thermocline and were sometimes in reduced relative abundance in a superficial layer of low salinity water. No relationship was apparent between the mean depth of eggs on individual hauls and wind speed.
16-18 Jun 96 Surface temperature

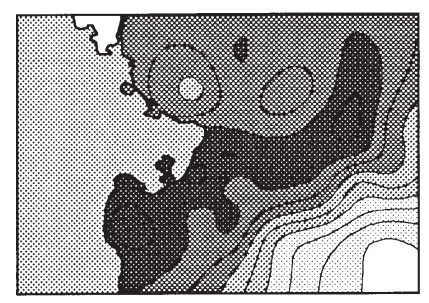

Surface salinity

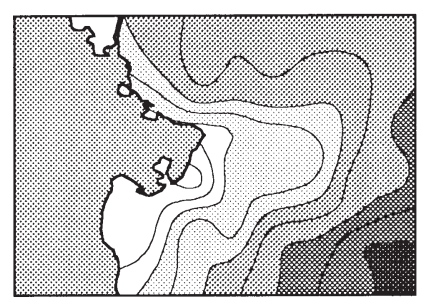

$0-20 \mathrm{~m} \Delta \sigma_{\mathrm{t}}$

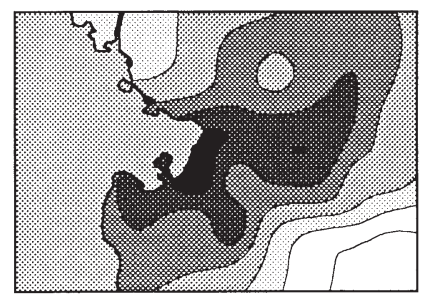
tion on the 2 bongo grids
Fig. 3. Surface temperature, surface salinity and water column stratifica-
2-4 Jul 96

$\left({ }^{\circ} \mathrm{C}\right) \quad$ Surface temperature

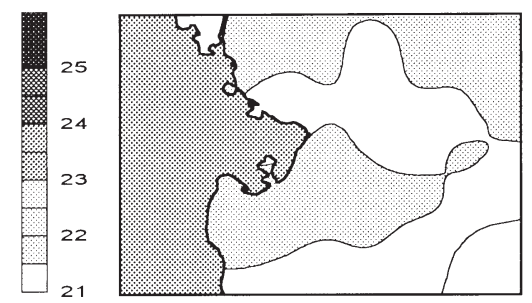

(units)

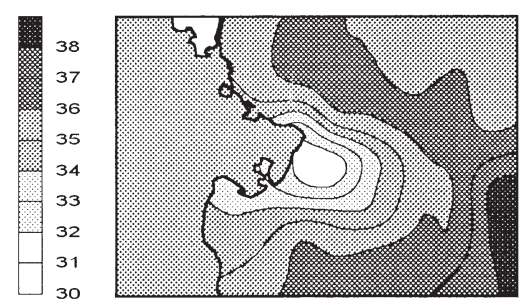

$\left(\mathrm{kg} \mathrm{m}^{-3}\right)$
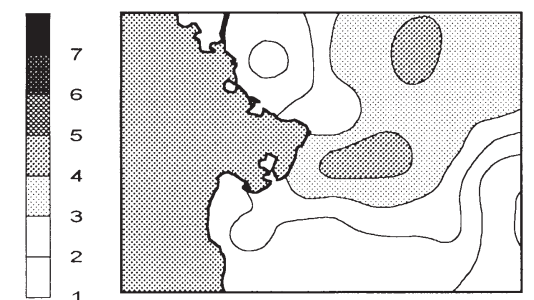


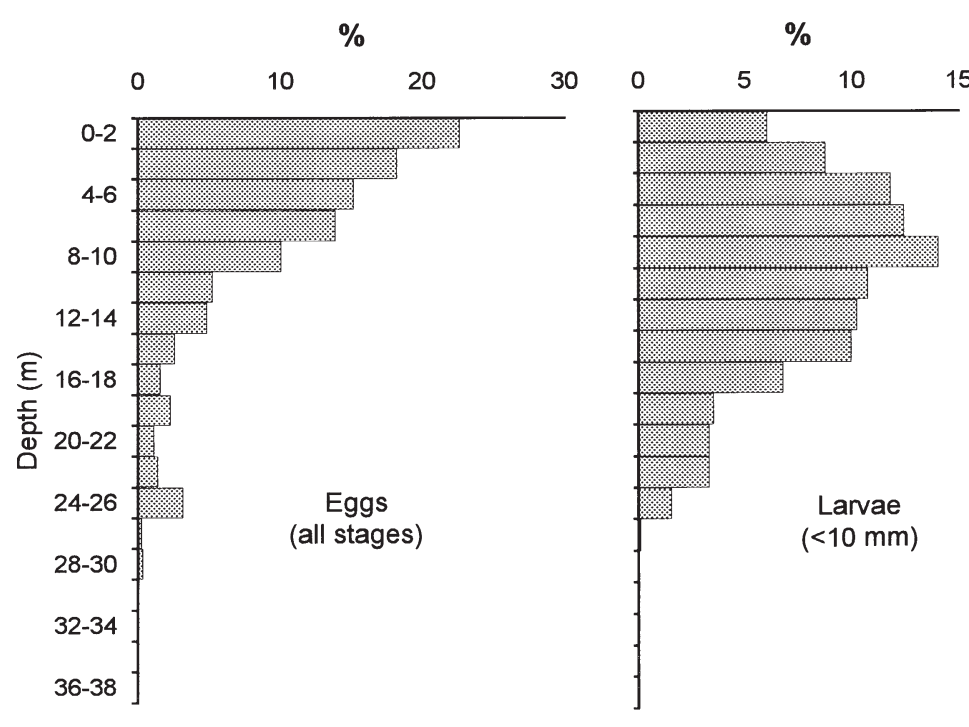

Fig. 4. Engraulis encrasicolus. Mean vertical distribution of eggs and larvae from all Longhurst-Hardy plankton recorder (LHPR) sampling combined

Haul to haul variability in the vertical distributions of anchovy larvae was greater than for the eggs. Larvae were also generally deeper in the water column than the eggs, with relatively few larvae in the top few meters of the water column where the lowest salinities occurred, or below about $20 \mathrm{~m}$ depth at the bottom of the mixed layer (Fig. 4). A sub-surface peak of abundance was present at 8 to $10 \mathrm{~m}$ depth. There was no consistent relationship between the vertical distributions of larvae on individual hauls and hydrographic structure or wind speed.

\section{Geographical distribution of anchovy eggs and larvae}

The distribution of anchovy spawning on the first bongo grid, as indicated by egg abundance, was concentrated $\left(>400\right.$ eggs $\left.\mathrm{m}^{-2}\right)$ in both an inshore area around the Po delta and an offshore area extending towards the central Adriatic (Fig. 5).

The larval distributions of the first bongo grid all showed a similar west to east extension, with a clear offshore locus of abundance and a less persistent inshore concentration to the south-east of the Po delta. In general, the larval distributions were more discrete than those of the eggs and were more detached from the coast except locally around the Po delta. There was little change in distribution between succeeding larval length categories.

On the second bongo grid (2 to 4 July), spawning activity was more concentrated in inshore areas and around the delta of the River Po than on the first grid
(Fig. 5). Concentrations of larvae were again more discretely defined than the eggs and were aligned in a similar easterly direction offshore from the delta. As on the first grid, larvae were generally in relatively low abundance in areas adjacent to the coast and away from the delta.

\section{Mortality rates}

The night: day catch ratio of anchovy larvae varied between 1.31 (for larvae $4.5 \mathrm{~mm}$ in length) and 3.25 (at $9.5 \mathrm{~mm}$ ). The systematic bias of values from a theoretical unity (for random sampling) is due to more sampling having taken place in areas of higher larval abundance at night compared with the day, at least for the smaller larval sizes $(<\sim 7 \mathrm{~mm})$, which are not liable to active escapement. Only for the largest size category, at a median length of $9.5 \mathrm{~mm}$, was there any indication of possible under-sampling of larvae during the day. Results from combined day and night sampling for all larval length categories have been used in the following mortality calculations, with over-estimation of the mortality rate being a possibility for the largest larvae only (8.5 to $9.5 \mathrm{~mm}$ long). Under-estimation of mortality rates, due to extrusion of the smallest larvae through the net mesh, is unlikely to have been a serious problem at the $280 \mu \mathrm{m}$ mesh size used in the bongos (Somarakis et al. 1998).

On the first bongo grid, mortality rates varied between 22.9 and $51.0 \% \mathrm{~d}^{-1}$, with no clear trend in change from stage to stage (Fig. 6, Table 3). On the second grid, there was a progressive decline in mortality from $64.2 \% \mathrm{~d}^{-1}$ for larvae $3.5 \mathrm{~mm}$ in length, to $10.8 \% \mathrm{~d}^{-1}$ for larvae at $9.5 \mathrm{~mm}$. Thus, during the earlier stages of development (<6 mm in larval length), mortality rates were comparable or relatively higher on the second grid than on the first; during subsequent development mortality rates were lower on the second grid, particularly for the largest size category of larvae (8.5 to $9.5 \mathrm{~mm}$ in length; Fig. 6). Linear regressions (Fig. 6) showed no significant difference (at $p<0.01$ ) in daily mortality rates between the 2 bongo grids $\left(43.2 \% \mathrm{~d}^{-1}\right.$ on the first and $44.7 \% \mathrm{~d}^{-1}$ on the second).

Geographical variability in mortality rates was investigated by plotting sub-sets of abundance data according to surface salinity or stratification at each bongo station (Fig. 6). For each bongo grid, the mortality curves were similar (no significant differences in linear regressions at $\mathrm{p}<0.01$ ) both to overall mortality and between the different sub-sets. A more constant mortality rate is seen in all data sets for the first grid, compared with a generally progressive decrease in mortality rates with larval size on the second grid. 


\section{Geographical distribution and abundance of potential food particles}

Based on the observed diet of anchovy larvae (Conway et al. 1998, Tudela et al. 2002), the potential food particles available for larvae on both bongo grids were predominantly the naupliar and copepodite stages of copepods; of these, the larger organisms comprising Oithona and 'other copepods', made a relatively greater contribution when converted from numerical abundance to dry weight (Fig. 7).

The different food components (Fig. 7) all showed similar distribution patterns, both between the 2 bongo grids and within each grid (cross-correlations of abundance of the different food components by station, all significant on the first bongo grid at $\mathrm{p}<0.01$, and on the second grid, $83 \%$ of all combinations significant at $\mathrm{p}<0.05)$. On the first grid, higher food concentrations were recorded both close inshore and in an easterly directed lobe from the Po delta (Fig. 8). By the second grid, the areas of higher food abundance were restricted to waters immediately adjacent to the delta. Mean numerical abundance of food particles on the second bongo grid was $58.8 \%$ of the level on the first grid (110.1 and 64.7 particles $\mathrm{l}^{-1}$ on the first and second grids, respectively). The reduction in terms of dry weight was more marked, the second grid being only $52.9 \%$ of the level on the first grid, due, in particular, to a decrease in numbers of the relatively large copepodites including Oithona spp.

\section{Vertical distribution and abun- dance of food particles}

In general, potential food items were somewhat more evenly distributed through the water column than were the larvae (Figs. 4 \& 9), but with a similar increase in abundance towards the surface. There was considerable consistency within sets of consecutive hauls at the same station in the general depth profile of potential food particles (e.g. at Stn 12; Fig. 10), more so than was observed for the anchovy larvae. This observation was supported by paired $t$-tests for all day/night pairs of hauls, which showed no significant differences ( $p<0.05)$ between either: (1) the mean or the maximum abundance on each haul (see also Fig. 12); (2) the
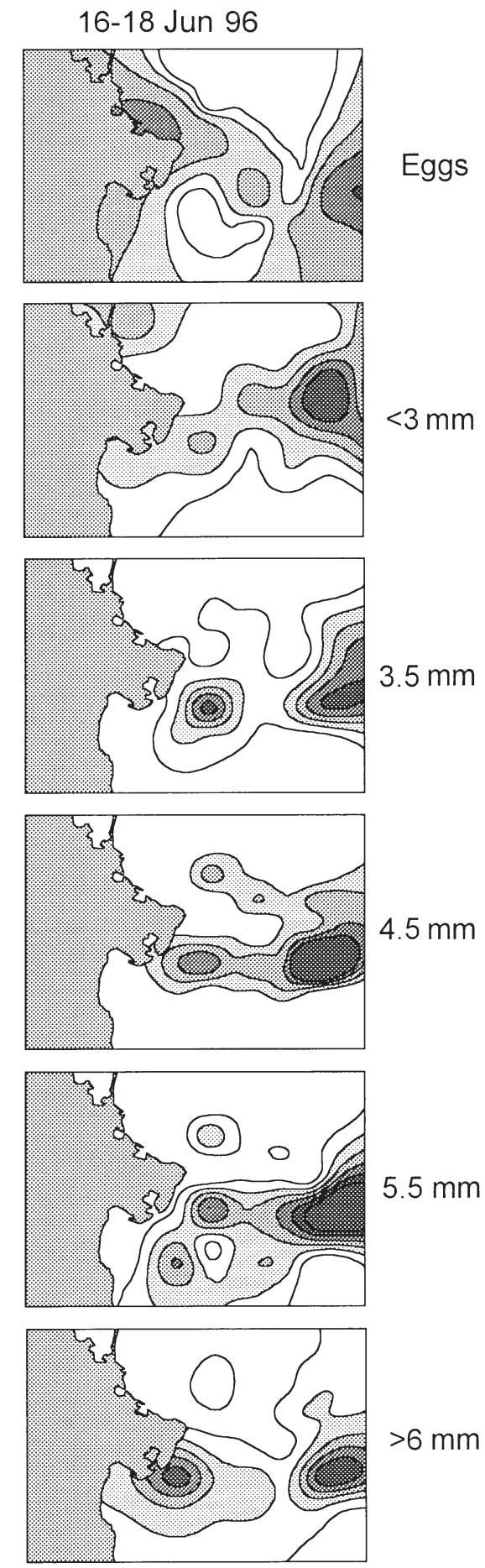

Fig. 5. Engraulis encrasicolus. Con
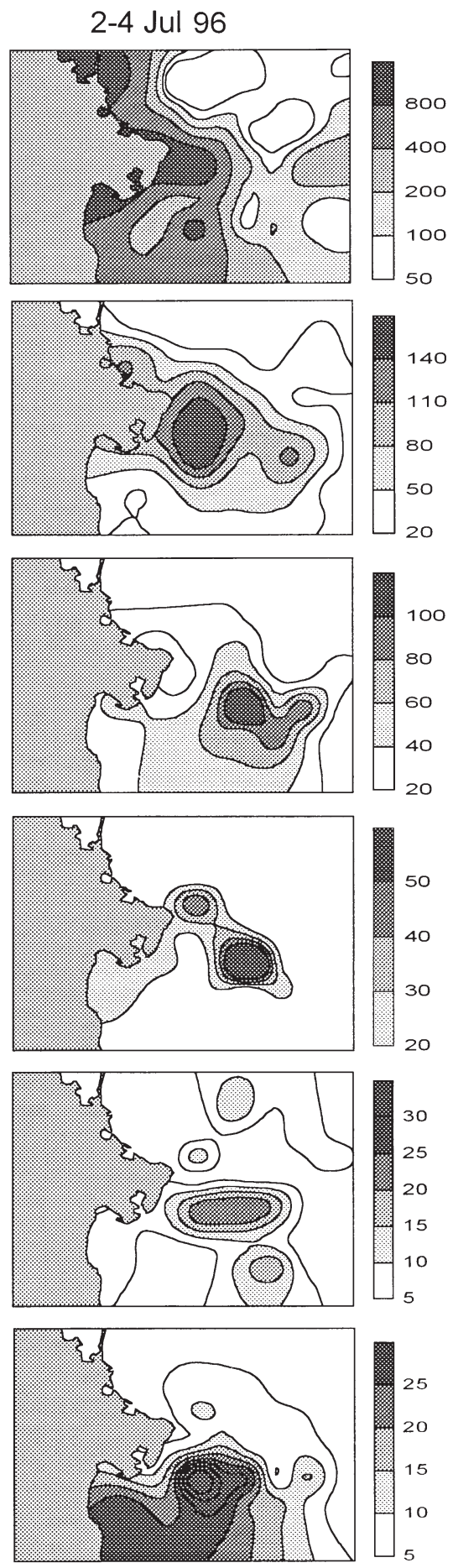

bongo grids 

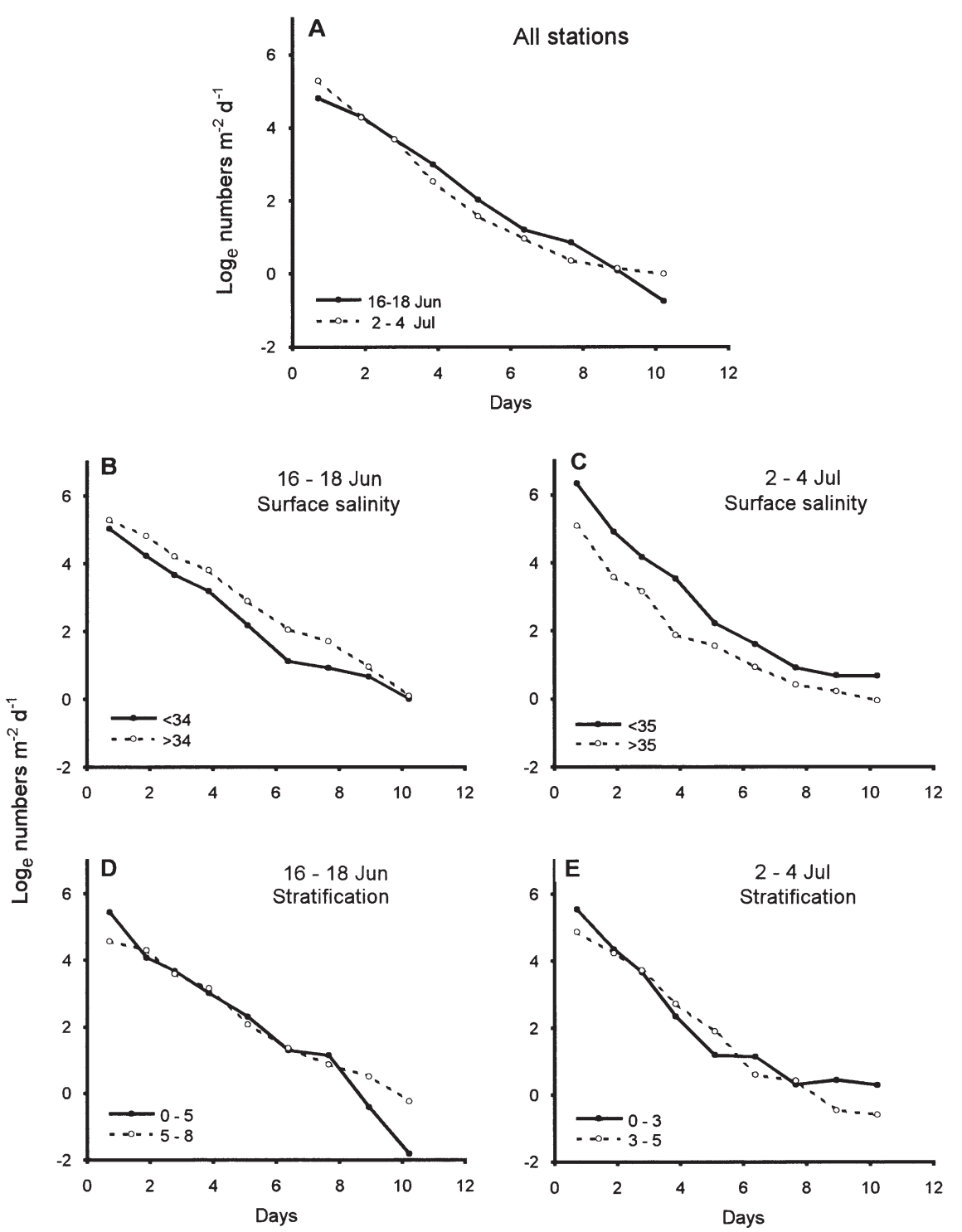

Fig. 6. Engraulis encrasicolus. Survival curves from eggs to larvae $10.23 \mathrm{~d}$ old (equivalent to larvae at a median length of $9.5 \mathrm{~mm}$ ) for (A) all stations (see also Table 3) and (B), (C), (D) and (E) sub-sets of stations separated by surface salinity and water column stratification ( 0 to $20 \mathrm{~m}, \Delta \sigma_{\mathrm{t}}$, see Fig. 3 )

abundance at any 1 depth interval to mean abundance throughout the water column was mostly between 1.5 and 2.8. These 2 parameters were inversely related, such that as the maximum abundance of potential food particles increased, then the depth of occurrence of the maximum tended to be at a shallower depth (Fig. 11A).

The relationship between the vertical concentration of food particles and water column structure is shown in Fig. 11B, where the ratio of maximum to mean potential food particle abundance (concentration ratio) is plotted against the degree of stratification (0 to $15 \mathrm{~m}$ density difference). Excluding the 4 hauls on which there were concentration ratios $>3$, there is a significant (at $\mathrm{p}<0.01$ ) positive linear relationship between these 2 parameters. The 4 'excluded' hauls with concentration ratios between 3.8 and 5.2, were taken 2 each at Stns 34 and 12 on July 10 and 11 , respectively; this being towards the end of the cruise period when stratification was rapidly increasing with the re-establishment of settled weather and high river outflow (see Fig. 2).

The time sequence of changes in food availability based on the LHPR vertical distribution sampling is shown in Fig. 12, with corresponding temperature and salinity profiles in Fig. 13. The reliability of the measurements of potential food abundance is supported by the consistency of both the mean and maximum values recorded on consecutive hauls on each station visit (Fig. 12). Food abundance at the inshore Stn 14 was generally higher and more consistent than at the other 3 sta-

depth at which the maximum abundance occurred; or (3) the dispersion index. Conversion of the $53 \mu \mathrm{m}$ microzooplankton from number $\mathrm{l}^{-1}$ to dry weight $\left(\mu \mathrm{g} \mathrm{l}^{-1}\right)$ had only a minor influence on their vertical distribution profiles; since copepodites were generally slightly deeper in the water column than the smaller sized nauplii, there was a tendency for the plots of dry weight to have a slightly higher representation of biomass at depth than the corresponding plots of numerical abundance (Fig. 10).

The depth of maximum abundance of potential food particles on individual LHPR hauls was mostly within the range 3 to $8 \mathrm{~m}$ and the ratio of maximum food tions, either as mean abundance through the water column or as the maximum recorded in any 1 depth stratum (maximum abundance on the different sampling visits between 77.7 and 144.6 particles $\mathrm{l}^{-1}$ ). At Stn 14, the water column was stratified on all LHPR sampling visits (Fig. 13); on 3 occasions, this was due to a combination of temperature and salinity, but on 27 June, during the period of stronger winds, when there was little thermal structure, stratification was maintained by an upper layer of markedly low salinity. At Stns 12 and 37 on June 27 and 29, respectively, there was little stratification and the maximum food levels were correspondingly low (16.4 and 43.3 parti- 
Table 3. Engraulis encrasicolus. Mortality rates for eggs and larvae on the 2 Bongo grids

\begin{tabular}{|lccc|}
\hline $\begin{array}{l}\text { Stage/ } \\
\text { length } \\
\text { (mm) }\end{array}$ & $\begin{array}{c}\text { Mean age } \\
\text { post-fertilization } \\
\text { (d) }\end{array}$ & $\begin{array}{c}\text { 16-18 Jun } \\
\text { Daily } \\
\text { mortality (\%) }\end{array}$ & $\begin{array}{c}\text { 2-4 Jul } \\
\text { Daily } \\
\text { mortality (\%) }\end{array}$ \\
\hline $\begin{array}{l}\text { Egg to }<3 \\
<3 \text { to } 3.5\end{array}$ & 1.44 & 34.2 & 53.6 \\
3.5 to 4.5 & 2.35 & 51.0 & 50.4 \\
4.5 to 5.5 & 3.26 & 46.8 & 64.2 \\
5.5 to 6.5 & 5.47 & 50.0 & 49.8 \\
6.5 to 7.5 & 7.03 & 44.1 & 36.1 \\
7.5 to 8.5 & 8.31 & 22.9 & 34.7 \\
8.5 to 9.5 & 9.59 & 41.5 & 15.3 \\
Overall & & 44.8 & 10.8 \\
\hline
\end{tabular}

cles $\mathrm{l}^{-1}$ ). The water column remained mixed and food abundance low (maximum of 54.8 particles $\mathrm{l}^{-1}$ ) on the subsequent visit to Stn 37; whereas, with the development of temperature and salinity structure at Stn 12, the maximum observed abundance of food particles increased to 163.2 particles $\mathrm{l}^{-1}$ (Figs. 12 \& 13). At Stn 34 , there was intermediate stratification on both station visits, between which the maximum food abundance increased from 49.4 to 147.5 particles $\mathrm{l}^{-1}$.

\section{DISCUSSION}

Results from the 2 bongo grids showed localised spawning of anchovy adjacent to the coast and in the low salinity outflow region of the River Po (Fig. 5). Previously, Piccinetti et al. (1980) had indicated a general concentration of anchovy eggs in this region, but did not link this specifically to the outflow hydrography. Elsewhere, a similar selection of river outflow regions for anchovy spawning has been noted by Sabates (1990) in the Mediterranean, and by Motos et al. (1996) and Koutsikopoulos \& Le Cann (1996) in the Bay of Biscay. The same association with river plumes has also been described for co-generics in Japanese waters (Engraulis japonica, Funakoshi 1984) and off the east coast of North America (E. mordax, Richardson 1980).

Anchovy larvae were distributed farther offshore than the eggs (Fig. 5), consistent with an initial easterly drift controlled by the hydrodynamically driven outflow regime of the River Po under low wind stress (Malanotte-Rizzoli \& Berga- masco 1983, Barale et al. 1986, Bergamasco \& Barale 1988). There was less net displacement and dispersion of succeeding larval stages, possibly reflecting a degree of retention in the river plume due to some combination of behavioural and hydro-mechanical forces. One difference in this pattern was on the second bongo grid for larvae $>6 \mathrm{~mm}$ in length (from about $8 \mathrm{~d}$ after spawning), which were more dispersed and distributed farther to the south. This may have been the result of the strong north-westerly winds experienced during their earlier development, since, at high levels of wind stress, river plumes may be largely wind-driven (Gelfenbaum \& Stumpf 1993).

Results from the bongo sampling on the 2 grids showed that the availability of potential food for anchovy larvae was higher both inshore and around the outflow plume of the Po (Fig. 8). River outflows are generally recognised as favourable areas for fish spawning (Grimes \& Kingsford 1996) due to enhanced production associated with increased nutrient input. This has been shown for the River Po (e.g. Fonda Umani et al. 1992), which dominates the distribution and production of phytoplankton and zooplankton in the northern Adriatic (Gilmartin \& Revelante 1981,
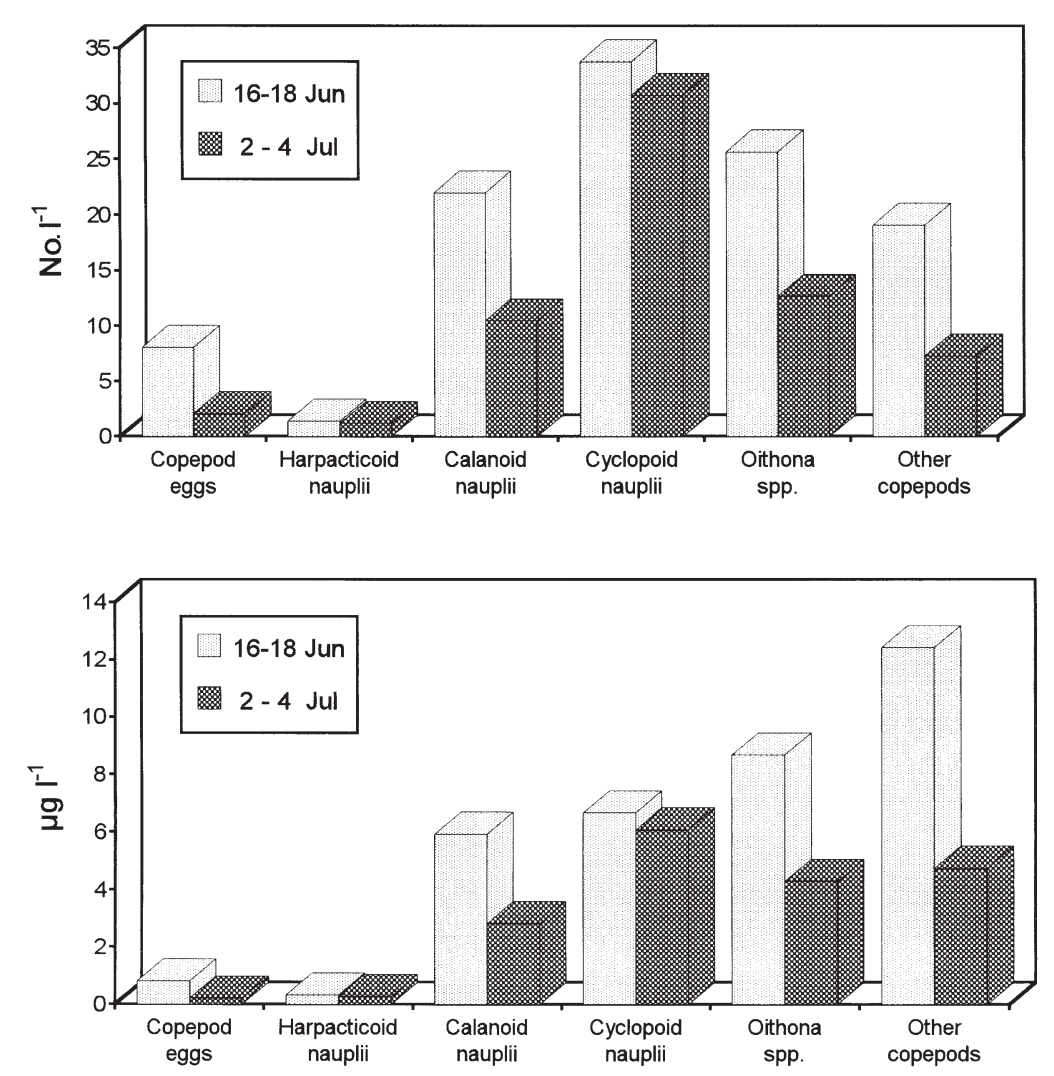

Fig. 7. Relative abundance of the different potential food particles for anchovy larvae for all stations combined on the 2 bongo grids plotted as numerical abundance (no. $\mathrm{l}^{-1}$ ) and dry weight $\left(\mu \mathrm{g} \mathrm{l}^{-1}\right)$ 

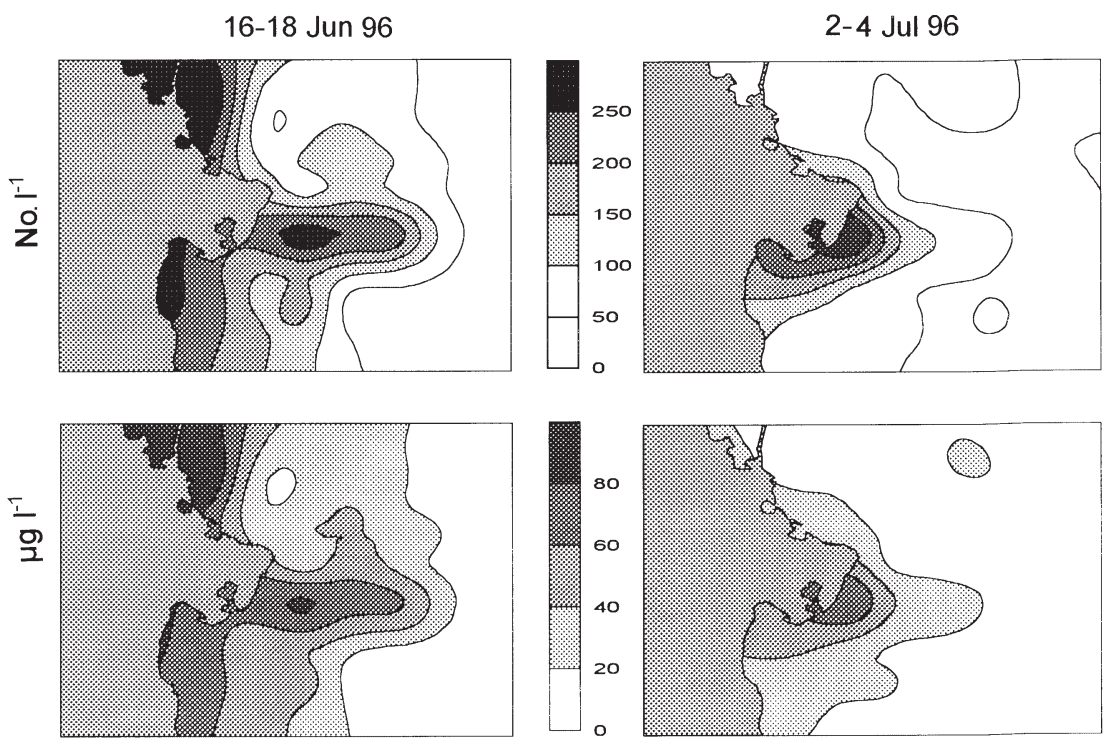

Fig. 8. Distribution and abundance of the combined potential food items for anchovy larvae on the 2 bongo grids plotted as numerical abundance (no. $\mathrm{l}^{-1}$ ) and dry weight $\left(\mu \mathrm{g} \mathrm{l}^{-1}\right)$

Smodlaka \& Revelante 1983, Fonda Umani 1996). Considering that the present sampling was restricted to a particularly productive area, the observed integrated levels of potential food abundance, in the range of 10 to $100+$ particles $\mathrm{l}^{-1}$, are comparable with other estimates from elsewhere in the Adriatic (maximum of 61 and 27 nauplii $1^{-1}$, Kršinić 1982 and Regner et al. 1987, respectively) and, as expected, are somewhat higher than typical measurements from temperate coastal seas (e.g. Petersen \& Ausubel 1984, Coombs et al. 1992, Ferron \& Leggett 1994). Although there was a marked reduction in mean potential food abundance on the second bongo grid (to 58.6\% the level on the first grid), Conway et al. (1998) observed that on the

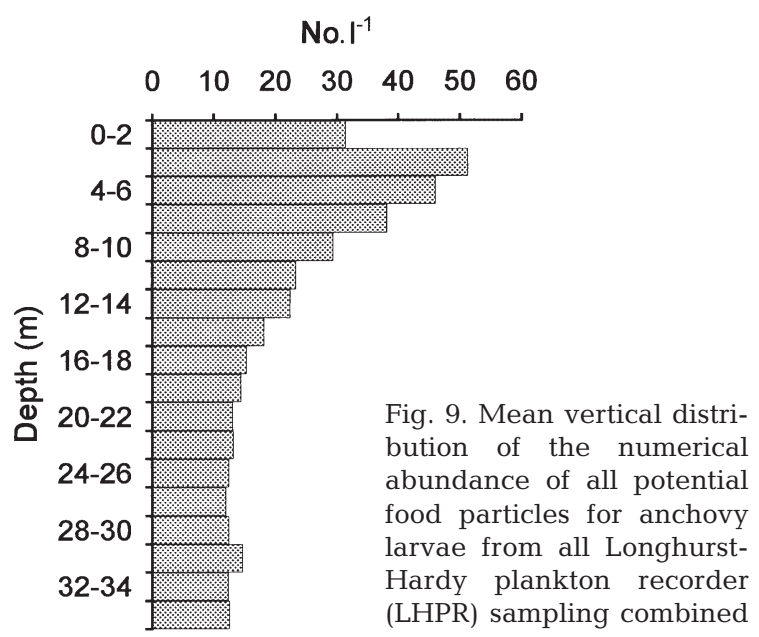

second grid, the overall feeding success of anchovy larvae was actually higher than on the first grid and because of changes in prey selection, energetically there was probably little overall difference in larval feeding success between the 2 bongo grids. This is also a reflection of the more localised distribution of larvae on the second bongo grid to the immediate outflow plume, where food levels were at similar concentrations as on the first grid (Figs. $5 \& 8$ ).

Furthermore, the measures of potential food availability from the depth-integrated bongo tows are likely to underestimate the concentrations actually perceived by the larvae, since the LHPR sampling showed that the maximum abundance of potential food particles at a single depth on each haul was frequently between 1.5 and 2.8 times the mean water column concentrations. The existence of modest sub-surface peaks in abundance of potential food particles is consistent with previous information on the vertical distribution of microzooplankton from the Adriatic and elsewhere (Kršiníc 1982, Revelante \& Gilmartin 1990, Coombs et al. 1992). Because the vertical mobility of fish larvae (e.g. Neilson \& Perry 1990) enables them to locate and exploit layers of aggregated food particles, the most appropriate measure of food availability for larvae is taken here as the maximum abundance in a single depth stratum (i.e. modal abundance).

Both eggs and larvae of anchovy were restricted mostly to the top 10 or $20 \mathrm{~m}$ of the water column, the increase in abundance of eggs towards the surface and the sub-surface peak of larvae being consistent with observations on the vertical distribution of ichthyoplankton in general (Conway et al. 1997) and, specifically for anchovy, both in the Adriatic (Regner 1972) and elsewhere (Ré 1987, Palomera 1991). The vertical distributions of potential food organisms showed that they were generally more dispersed through the water column than the larvae, this could possibly be related to their heterogeneous composition. The peaks of food concentration were nevertheless mostly in the top $10 \mathrm{~m}$ of the water column in a similar depth range as the highest numbers of anchovy larvae.

The links between hydrographic and meteorological conditions and food availability were supported by 2 lines of evidence from the LHPR results. Firstly, there was a positive relationship between the ratio of maximum:mean food abundance (i.e. vertical concentration 


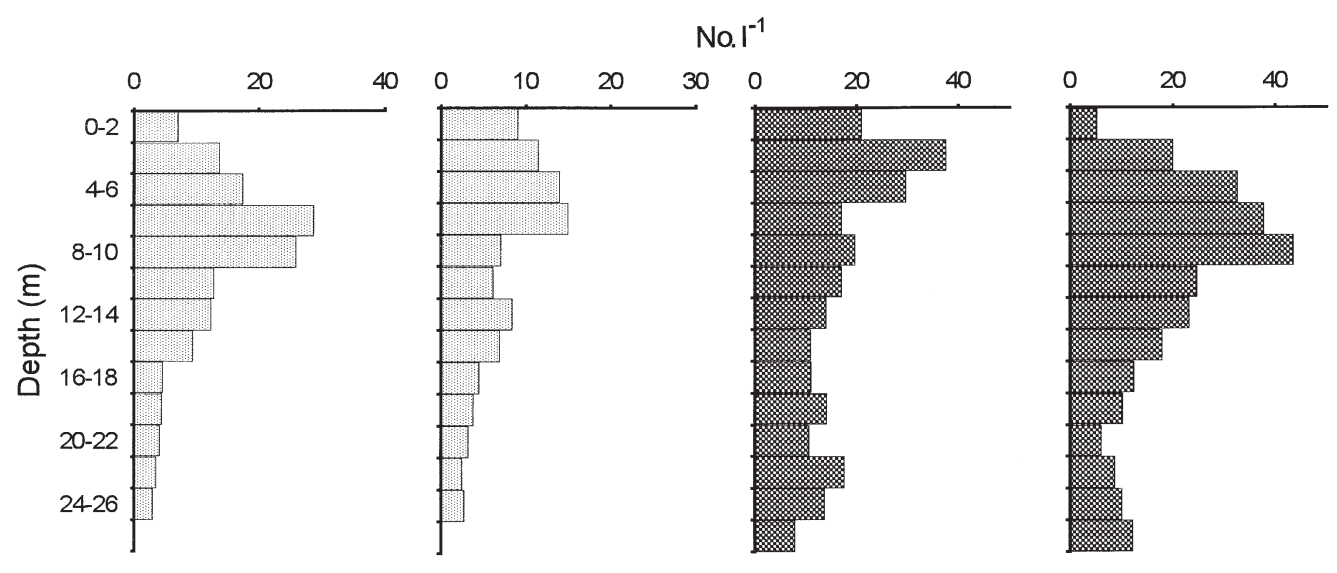

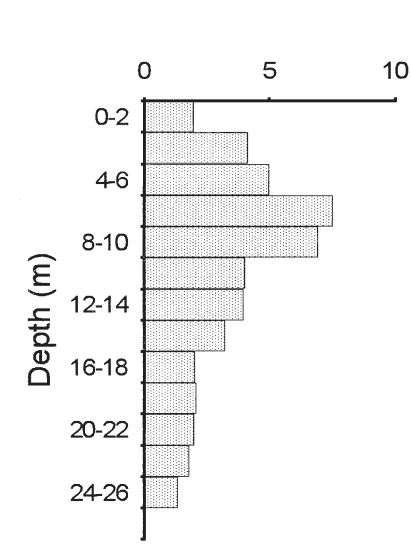

$12: 40 \mathrm{~h}$

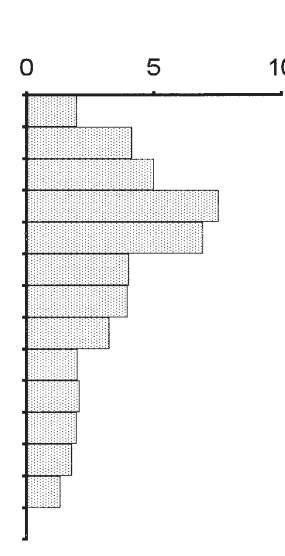

$16: 00 \mathrm{~h}$ $\mu g \mathrm{I}^{-1}$

100

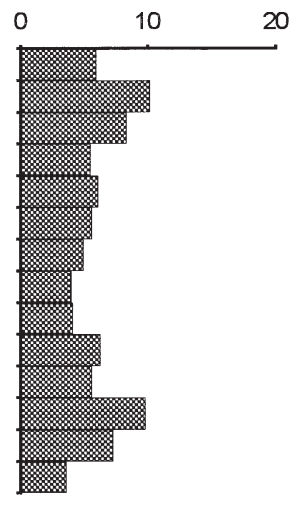

$22: 30 \mathrm{~h}$

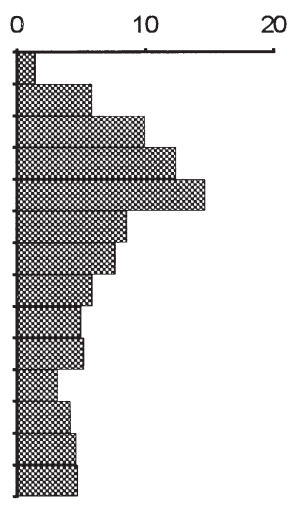

$02: 20 \mathrm{~h}$

Fig. 10. Vertical distribution of all potential food particles for anchovy larvae at Stn 12 on 6-7 July on 4 consecutive LonghurstHardy plankton recorder (LHPR) hauls (day/light shading, night/dark shading), plotted as numerical abundance (no. $\mathrm{l}^{-1}$ ) and dry weight $\left(\mu \mathrm{g}^{-1}\right)$
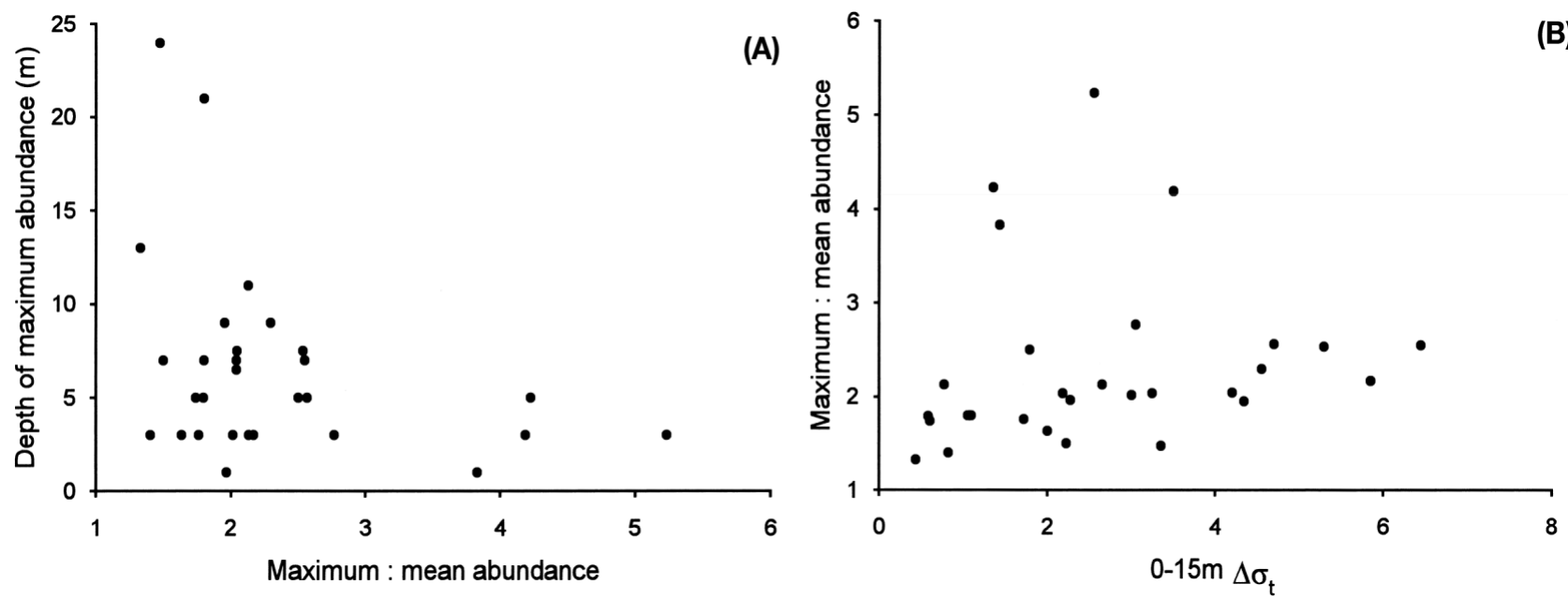

Fig. 11. Individual Longhurst-Hardy plankton recorder (LHPR) hauls. (A) Depth of maximum abundance of potential food particles for anchovy larvae in relation to the ratio of maximum : mean food particle abundance through the water column, (B) ratio of maximum:mean abundance of potential food particles through the water column in relation to the water density difference between 0 and $15 \mathrm{~m}$ depth 

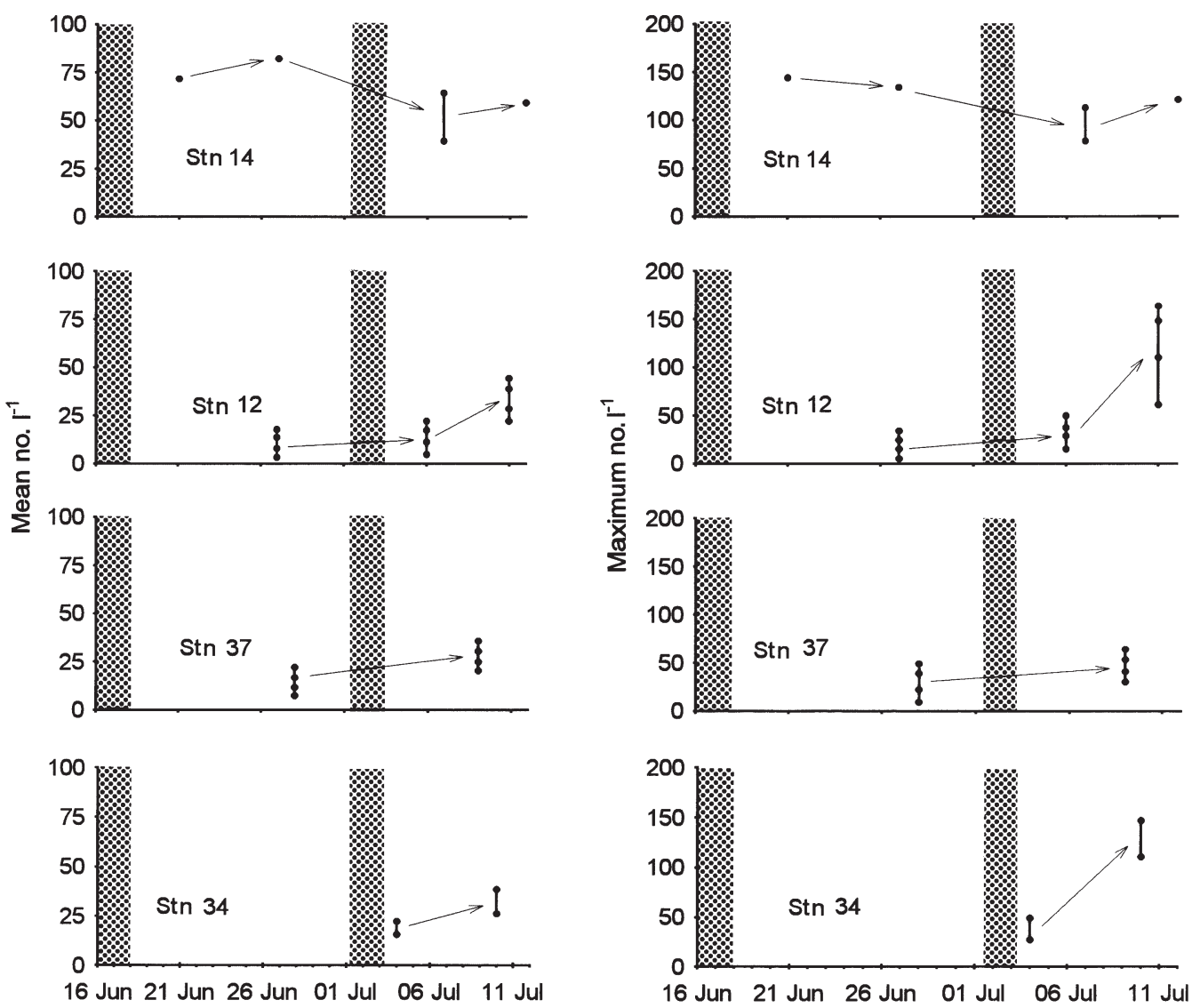

Fig. 12. Availability of potential food particles for anchovy larvae on Longhurst-Hardy plankton recorder (LHPR) hauls plotted as the mean numerical abundance down the water column (left-hand plots) and as maximum abundance on each haul (righthand plots). Vertical lines join results from consecutive hauls on each station visit. The stippled bars show the sampling periods for the 2 bongo grids

ratio) and stratification in the top $15 \mathrm{~m}$ of the water column. Secondly, the absolute levels of food abundance were generally higher at stations when stratification was well developed. This accounts for the maintenance of consistently favourable feeding conditions $\left(>77\right.$ particles $^{-1}{ }^{-1}$ ) at the inshore Stn 14 where stratification was maintained by superficial low salinity river run-off during the period of unsettled weather. At the other LHPR sampling stations, there were lower levels of stratification during the poor weather in the middle of the cruise period and the levels of food availability were correspondingly lower (in the range 15 to 50 particles $\mathrm{l}^{-1}$ ); with the return of more stable weather and stratification towards the end of the cruise period, levels of food increased at these stations to between 30 and 150 particles $\mathrm{l}^{-1}$.

Although starvation is not necessarily the prime determinant of recruitment success (Leggett \& Deblois 1994), the conclusion on the equivalence of food intake by larvae on the 2 bongo grids is supported by the similarity of the mean daily mortality rates (43.2 and
$44.7 \%$ ). These values are comparable with, but somewhat higher than, previous mortality estimates for the planktonic stages of anchovy in the Adriatic. Piccinetti et al. (1982) derived a best estimate of $35.1 \%$ mortality $\mathrm{d}^{-1}$ for post-larvae 3 to $8 \mathrm{~mm}$ in length in the northern Adriatic, while Dulčić (1995) gave daily mortality rates of $38.4 \%$ for the egg and larval stages (up to about $4.5 \mathrm{~d}$ post-fertilization) and $40.4 \%$ for the post-larvae; however, the rates given by Dulčić (1995) were considered to be high due to the prevailing poor biotic conditions. Elsewhere, Palomera \& Lleonart (1989) reported mortality rates of 15.6 to $43.8 \% \mathrm{~d}^{-1}$ for larvae up to $15 \mathrm{~d}$ old off the Mediterranean coast of Spain.

The mortality rates observed in the present study are therefore not unrealistic, but are relatively high considering the conclusion that feeding conditions were generally favourable. Among the other potential influences on mortality are predation, which is the most intractable problem, and sampling artifacts. Somarakis et al. (1998) concluded that net avoidance by anchovy larvae was significant from a larval length of $6.5 \mathrm{~mm}$, 

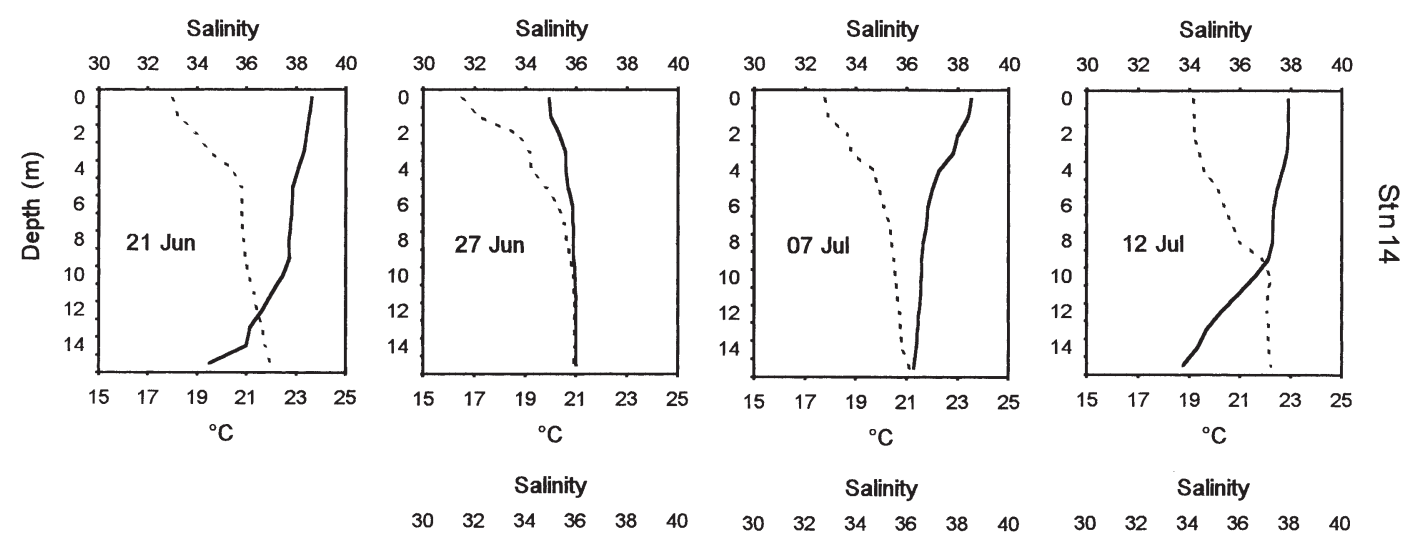

which, for the present study, implies some potential over-estimation of mortality rates for larvae above that length. On this basis, a reduction of the mortality rates of the larger larvae would tend to reinforce the precept of decreasing mortality rate with larval size (e.g. Anderson 1988). Such size-related mortality is apparent in the data for the second bongo grid (Fig. 6). However, Piccinetti et al. (1982) found net avoidance by anchovy larvae from a length of about $8 \mathrm{~mm}$ and that avoidance was less pronounced in the more turbid waters of the northern Adriatic. Therefore, in the present sampling in the Po outflow, which represents the most turbid waters of the Adriatic, larvae may have been sampled effectively to lengths approaching $10 \mathrm{~mm}$.

It should be recognised that the mortality rates in this study were derived from surveys each effectively at a single point in time, that the entire discrete distribution was not fully covered (especially for the first grid; see Fig. 5) and a single cohort was not followed over time. Thus, the assumptions of a constant rate of egg production, the absence of immigration/ emigration and consistency in mortality between each length class over time can each introduce a bias. Despite these limitations, the similarity in the mortality curves between different hydrographic regimes within each bongo grid (Fig. 6) support the estimates as being relatively robust.

The conclusions of the present study are that the region around the mouth of the River Po is generally favourable for the survival of anchovy larvae, at least in part, due to the additional water column stability
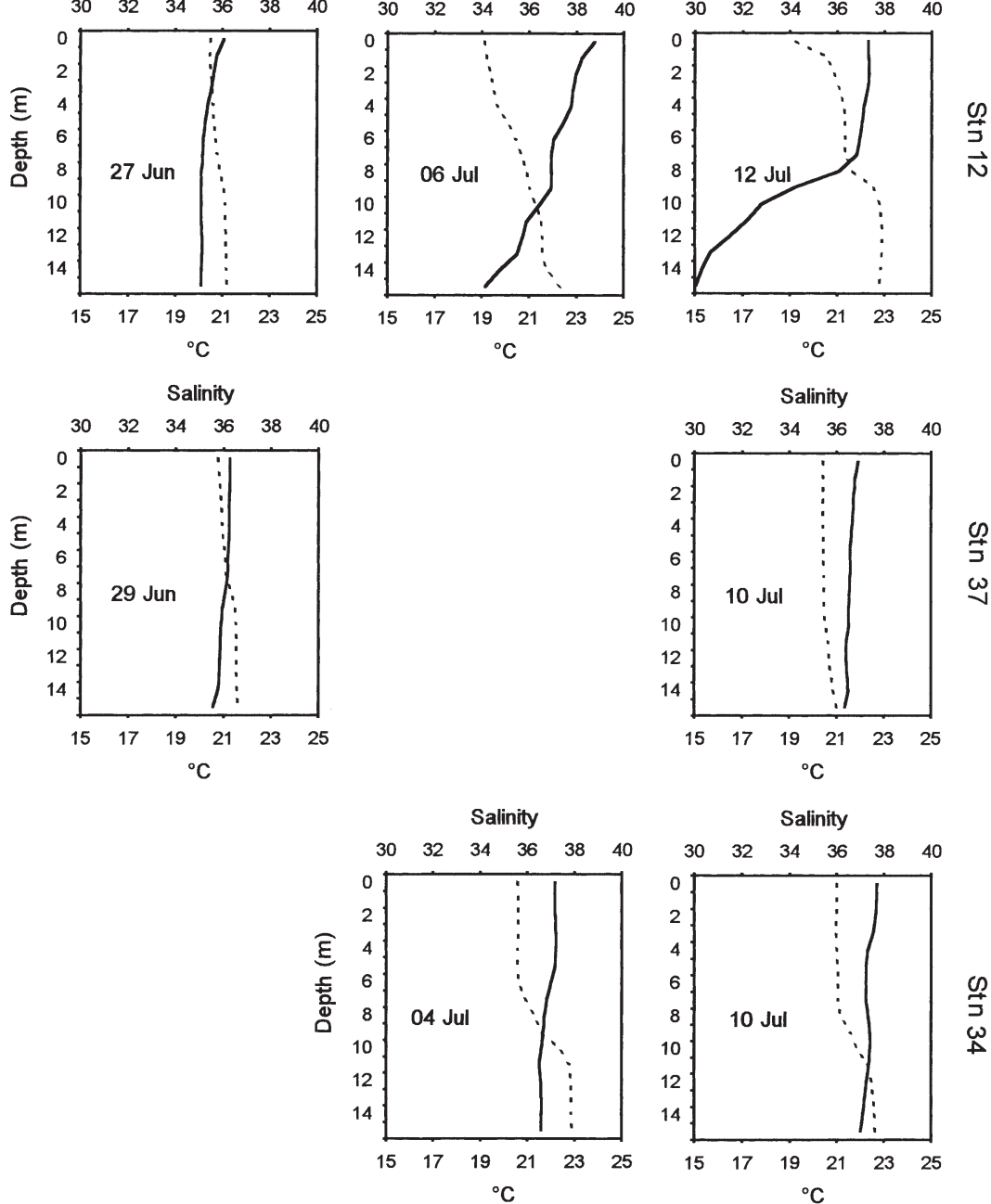

Fig. 13. Temperature (continuous line) and salinity (dashed line) profiles in the upper $15 \mathrm{~m}$ of the water column on consecutive visits to the 4 Longhurst-Hardy plankton recorder (LHPR) stations. Scales are the same for all. Individual plots are positioned in the diagram to correspond schematically with the LHPR sampling dates and layout of Fig. 12

conferred by the superficial low salinity river outflow. This helps to maintain water column stratification and consequent vertical aggregations of food particles, which might otherwise be dispersed by wind mixing. 
Although the implication is that low winds and a stable water mass are beneficial for larval survival (e.g. Peterman \& Bradford 1987), a simple mechanistic relationship between wind speed and larval survival is not necessarily expected due to other non-linear interactions, such as predator/prey contact rates (Sundby 1997) or enhancement of production by water column mixing (Bakun 1996). Furthermore, within the limitations of the mortality estimates, there was no direct relationship with either surface salinity or water column stratification (Fig. 6). This indicates that there is no simple extrapolation from enhanced water column stability from fresh water outflow and consequent concentration of food particles, and the resultant survival of anchovy larvae.

Acknowledgements. Funding for this study was provided, in part, by the Direzione Generali Pesca e Acquicoltura, Ministero delle Risorse Agricole, Alimentari e Forestali and by the Istituto Centrale per la Ricerca scientifica e tecnologica Applicata al Mare (ICRAM), Rome.

\section{LITERATURE CITED}

Allain G, Petitgas P, Lazure P (2001) The influence of mesoscale ocean processes on anchovy (Engraulis encrasicolus) recruitment in the Bay of Biscay estimated with a 3-dimensional hydrodynamic model. Fish Oceanogr 10: 151-163

Anderson JT (1988) A review of size dependent survival during pre-recruit stages of fishes in relation to recruitment. J Northwest Atl Fish Sci 8:55-66

Bailey KM, Houde ED (1989) Predation on eggs and larvae of marine fishes and the recruitment problem. Adv Mar Biol 25:1-83

Bakun A (1996) Patterns in the ocean: ocean processes and marine population dynamics. California Sea Grant, La Jolla

Barale V, McClain CR, Malanotte-Rizzoli P (1986) Space and time variability of the surface color field in the northern Adriatic Sea. J Geophys Res 91:12 957-12 974

Bergamasco A, Barale V (1988) Comparison between coastal runoff patterns from CZCS imagery and from a general circulation model. In: Marani A (ed) Advances in environmental modelling. Elsevier, Amsterdam, p 395-404

Bergeron JP (2000) Effect of strong winds on the nutritional condition of anchovy (Engraulis encrasicolus L.) in the Bay of Biscay, Northeast Atlantic, as inferred from an early field application of the DNA/C index. ICES J Mar Sci 57: 249-255

Bombace G (1992) Fisheries of the Adriatic Sea. In: Colombo G, Ferrari I, Ceccherelli VU, Rossi R (eds) Marine eutrophication and population dynamics. Proc 25th Europ Mar Biol Symp. Olsen and Olsen, Fredensborg, Denmark, p 379-390

Borja A, Uriate A, Egaña J, Motos L, Valencia V (1998) Relationships between anchovy (Engraulis encrasicolus) recruitment and environment in the Bay of Biscay (1967-1996). Fish Oceanogr 7:375-380

Conway DVP, Coombs SH, Smith C (1997) Vertical distribution of fish eggs and larvae in the Irish Sea and southern North Sea. ICES J Mar Sci 54:136-147
Conway DVP, Coombs SH, Smith C (1998) Feeding of anchovy Engraulis encrasicolus larvae in the northwestern Adriatic Sea in response to changing hydrobiological conditions. Mar Ecol Prog Ser 175:35-49

Coombs SH, Nichols JH, Conway DVP, Milligan S, Halliday NC (1992) Food availability for sprat larvae in the Irish Sea. J Mar Biol Assoc UK 72:821-834

Coombs S, Giovanardi O, Conway D, Manzueto L, Halliday N, Barrett C (1997) The distribution of eggs and larvae of anchovy (Engraulis encrasicolus) in relation to hydrography and food availability in the outflow of the river Po. Acta Adriat 38:33-47

Cushing DH (1995) Population production and regulation in the sea. A fisheries perspective. Cambridge University Press, Cambridge

Dower JF, Miller TJ, Leggett WC (1997) The role of microscale turbulence in the feeding ecology of larval fish. Adv Mar Biol 31:169-220

Duka LA (1963) Pitanie licinok hamsi (Engraulis encrasicolus L.) v Adriticeskom more. Tr Sevastop Biol Stn 16:299-305

Dulčíc J (1995) Spawning of the anchovy Engraulis encrasicolus in the northern Adriatic Sea in 1989, the year of intensive blooms. Ann Istrian Mediterr Stud 7:55-60

Dulčić J, Kraljevic M (1996) Larval growth of anchovy, Engraulis encrasicolus (fishes) in the eastern Adriatic Sea. Vie Milieu 46:73-78

Economou AN (1987) Ecology of survival in some gadoid larvae of the northern North Sea. Environ Biol Fish 19:241-260

Ferron A, Leggett WC (1994) An appraisal of condition measures for marine fish larvae. Adv Mar Biol 30:217-303

Fonda Umani S (1996) Pelagic production and biomass in the Adriatic Sea. Sci Mar 60(Suppl 2):65-77

Fonda Umani S, Franco P, Ghirardelli E, Malej A (1992) Outline of oceanography and the plankton of the Adriatic Sea. In: Colombo G, Ferrari I, Ceccherelli VU, Rossi R (eds) Marine eutrophication and population dynamics. Proc 25th Europ Mar Biol Symp. Olsen \& Olsen, Fredensborg, p 379-390

Funakoshi S (1984) Food and survival of the early postlarvae of the Japanese anchovy, Engraulis japonica (Houttuyn) II. Distribution of anchovy larvae as related to occurence of the maximum layers of chlorophyll a concentration and copepod nauplius densities. Bull Jpn Soc Sci Fish 45: $21-30$

Gelfenbaum G, Stumpf RP (1993) Observations of currents and density structure across a buoyant plume front. Estuaries 16:40-52

Gilmartin M, Revelante N (1981) Regional variations in phytoplankton standing crops in the northern Adriatic Sea. Rapp P-V Reun Comm Int Explor Sci Mer Méditerr 27: 85-87

Grimes CB, Kingsford MJ (1996) How do riverine plumes of different sizes influence fish larvae: do they enhance recruitment? Mar Freshw Res 47:191-208

Hay SJ, Evans GT, Gamble JC (1988) Birth, growth and death rates for enclosed populations of calanoid copepods. J Plankton Res 10:431-454

Heath MR (1992) Field investigations of the early life stages of marine fish. Adv Mar Biol 28:1-174

Hunter JR, Alheit J (eds) 1994 International GLOBEC Small Pelagic Fishes and Climate Change program. Report of the First Planning Meeting, La Paz, Mexico, June 20-24, 1994. GLOBEC Report No 8, Globe International, Boston

Kendall AW Jr, Schumacher JD, Kim S (1996) Walleye pollock recruitment in Shelikof Strait: applied fisheries oceanography. Fish Oceanogr 5(Suppl 1):4-18 
Kornilova VP (1955) Nabludenie za rostom licinok i molodi Azovskoi hamsi v 1953. g. Tr Azovo-Chernomorsk Nauchno-Issled Inst Morsk Rybn Khoz Okeanogr. NIRO 16:193-200

Koutsikopoulos C, Le Cann B (1996) Physical processes and hydrological structures related to the Bay of Biscay anchovy. Sci Mar 60(Suppl 2):9-19

Kršinić F (1982) Microzooplankton in the Bay of Kastela and adjacent area. Acta Adriat 23:89-96

Lagadeuc M, Boule M, Dodson JJ (1997) Effect of vertical mixing on the vertical distribution of copepods in coastal waters. J Plankton Res 19:1183-1204

Lasker R (1975) Field criteria for survival of anchovy larvae: the relation between inshore chlorophyll maximum layers and successful first feeding. Fish Bull US 73:453-462

Leggett WC, Deblois E (1994) Recruitment in marine fishes: is it regulated by starvation and predation in the egg and larval stages? Neth J Sea Res 32:119-134

Lochmann SE, Taggart CT, Griffin DA, Thompson KR, Maillet GL (1997) Abundance and condition of larval cod (Gadus morhua) at a convergent front on Western Bank, Scotian Shelf. Can J Fish Aquat Sci 54:1461-1479

Malanotte-Rizzoli P, Bergamasco A (1983) The dynamics of the coastal region of the northern Adriatic Sea. J Phys Oceanogr 13:1105-1130

McFadzen IRB, Franceschini G (1997) The nutritional condition of larvae of anchovy (Engraulis encrasicolus L.) in the outflow of the River Po (Northern Adriatic). Acta Adriat 38: 49-64

Moser GH, Pommeranz T (1999) Vertical distribution of eggs and larvae of northern anchovy, Engraulis mordax, and of the larvae of associated fishes at 2 sites in the Southern California Bight. Fish Bull US 97:920-943

Motos L, Uriarte A, Valencia V (1996) The spawning environment of the Bay of Biscay anchovy (Engraulis encrasicolus L.). Sci Mar 60(Suppl 2):117-140

Nakata K, Zenitani H, Inagake D (1995) Differences in food availability for Japanese sardine larvae between the frontal region and the waters on the offshore side of Kuroshio. Fish Oceanogr 4:68-79

Neilson JD, Perry RI (1990) Diel vertical migrations of marine fishes: an obligate or facultative process? Adv Mar Biol 26: $115-168$

Palomera I (1991) Vertical distribution of anchovy eggs and larvae in stratified waters of the Western Mediterranean. Mar Biol 111:37-44

Palomera I, Lleonart J (1989) Field mortality estimates of anchovy larvae, Engraulis encrasicolus, in the western Mediterranean. J Fish Biol 35:133-138

Palomera I, Morales-Nin B, Lleonart J (1988) Larval growth of anchovy, Engraulis encrasicolus, in the western Mediterranean Sea. Mar Biol 99:283-291

Peterman RM, Bradford MJ (1987) Wind speed and mortality rate of a marine fish, the northern anchovy (Engraulis mordax). Science 235:354-356

Peterson WT, Ausubel SJ (1984) Diets and selective feeding by larvae of Atlantic mackerel Scomber scombrus on zooplankton. Mar Ecol Prog Ser 17:65-75

Piccinetti C, Piccinetti-Manfrin G, Specchi M (1980) The spawning of anchovy (Engraulis encrasicolus L.) in the north and central Adriatic Sea. Mem Biol Mar Oceanogr (Suppl) X:259-267

Piccinetti C, Regner S, Specchi M (1982) Preliminary data on

Editorial responsibility: Otto Kinne (Editor),

Oldendorf/Luhe, Germany larval and postlarval mortality of anchovy Engraulis encrasicolus (Linnaeus, 1758) in the northern and central Adriatic. Acta Adriat 23:449-456

Pipe RK, Coombs SH, Clarke KR (1981) On the sample validity of the Longhurst-Hardy Plankton Recorder for fish eggs and larvae. J Plankton Res 3:675-683

Ré P (1987) Ecology of the planktonic phase of the anchovy, Engraulis encrasicolus (Linnaeus, 1758), within the Mira estuary (Portugal). Invest Pesq 51:581-598

Regner S (1972) Contribution to the study of the ecology of the planktonic phase in the life history of the anchovy in the central Adriatic. Acta Adriat 14:1-40

Regner S (1985) Ecology of planktonic stages of the anchovy Engraulis encrasicolus (Linnaeus, 1758), in the central Adriatic. Acta Adriat 26:5-113

Regner S (1996) Effects of environmental changes on early stages and reproduction of anchovy in the Adriatic Sea. Sci Mar 60(Suppl 2):167-177

Regner S, Regner D, Marasovic I, Kršinić F (1987) Spawning of sardine, Sardina pilchardus (Walbaum, 1792), in the Adriatic under upwelling conditions. Acta Adriat 28: 161-198

Revelante N, Gilmartin M (1990) Vertical water column resource partitioning by a ciliated protozoan population under stratified conditions in the northern Adriatic. J Plankton Res 12:89-107

Richardson SL (1980) Spawning biomass and early life of northern anchovy, Engraulis mordax, in the northern subpopulation off Oregon and Washington. Fish Bull US 78:855-876

Richman J, Garrett C (1977) The transfer of energy and momentum by the wind to the surface mixed layer. J Phys Oceanogr 7:876-881

Ricker WE (1973) Linear regressions in fisheries research. J Fish Res Board Can 30:409-434

Rothschild BJ, Osborn TR (1988) Small-scale turbulence and plankton contact rates. J Plankton Res 10:465-474

Sabates A (1990) Changes in the heterogeneity of mesoscale distribution patterns of larval fish associated with a shallow coastal haline front. Estuar Coast Shelf Sci 30: 131-140

Smodlaka N, Revelante N (1983) The trends of phytoplankton production in the Northern Adriatic Sea: a twelve year survey. Rapp P-V Reun Comm Int Explor Sci Mer Méditerr 28:89-90

Somarakis S, Catalano B, Tsimenides N (1998) Catchability and retention of larval European anchovy, Engraulis encrasicolus, with bongo nets. Fish Bull US 96:917-925

Sundby S (1997) Turbulence and ichthyoplankton: influence on vertical distributions and encounter rates. Sci Mar 61(Suppl 1):159-176

Thompson AB, Harrop RT (1991) Feeding dynamics of fish larvae on Copepoda in the western Irish Sea, with particular reference to cod Gadus morhua. Mar Ecol Prog Ser 68:213-223

Tudela S, Palomera I, Quílez G (2002) Feeding of anchovy Engraulis encrasicolus larvae in the north-west Mediterranean. J Mar Biol Assoc UK 82:349-350

Williams R, Collins NR, Conway DVP (1983) The double LHPR system, a high speed micro- and macroplankton sampler. Deep-Sea Res 30:331-342

Zore-Armanda M, Gačíc M (1987) Effects of bura on the circulation in the North Adriatic. Ann Geofis 5b:93-102

Submitted: March 25, 1999; Accepted: October 22, 2002

Proofs received from author(s): January 30, 2003 